\section{Calcium Pantothenate and Burns}

SIR,-In view of the interesting correspondence precipitated in the columns of your Journal by the report of Dr. A. E. Milne et al. (July 14, p. 117) on the use of antihistamines in the treatment of burns, including that of Dr. S. B. Stoker on local heparin therapy in neutralizing the toxic products of burns (August 11, p. 360), we would like to add our experimental findings on another substance which in this case we found effective in significantly reducing mortality due to burns. Calcium pantothenate, when dissolved in physiological saline and administered intraperitoneally in doses of $100 \mathrm{mg}$. $/ \mathrm{kg}$. body weight before a lethal burn obtained by immersing $90 \%$ of the body surface of rats in water at $70^{\circ} \mathrm{C}$. for 15 seconds, increases the survival rate in rats as compared to controls receiving an equal volume of physiological saline solution. Statistical treatment of the number of animals surviving at 12, 24, 48, and 72 hours after the standardized burn indicated that at the $1 \%$ probability level calcium pantothenate/saline solution had a significantly greater protective action than saline alone. With equivalent doses of methionine dissolved in saline and given $1 \frac{1}{2}$ hours before the burn, the effect was the same as with saline alone, although Hazan and Treadwell, using the technique we adopted, reported a significant effect at higher doses of methionine (Proc. Soc. exp. Biol. N:Y., 1948, 68, 684).

The mechanism of action has not as yet been determined, nor is it known whether the effect is specific for this vitamin. It may be that in the extensive metabolic changes of burn shock the coenzyme A concentration of certain tissues becomes critical, thus increasing the requirement of pantothenic acid for binding into the cofactor. It would be of some interest to study clinically the effect of this substance in burn therapy.-We are, etc.,
George Washington University.
L. P. Munan.
Washington, D.C.
A. EINHEBER.

\section{POINTS FROM LETTERS}

\section{Treatment of Migraine}

Dr. N. N. Iovetz-Tereshchenko (Georgetown, British Guiana) writes: With reference to your annotation on the treatment of migraine (September 1, p. 538) and the letters from Dr. H. C. Stewart and Dr. H. S. C. Wight (September 15, p. 673) it is rather surprising that no mention is made of the fact that ergotamine tartrate is more efficient when allowed to dissolve under the tongue than when swallowed, and that an injection of atropine prevents the nausea which sometimes occurs with light dosage or in sensitive persons.

\section{Cigarette Smoking and the Hands}

- Dr. J. G. Bennetr (Woodley, Cheshire) writes: The article by Dr. J. T. Shepherd (October 27, p. 1007) which stresses the connexion between dead hands and tobacco addiction bears. on my own case. I am 63 years old, and I have smoked on an average between 20 and 30 cigarettes daily since the age of 18 . Up to the approximate age of $60 \mathrm{I}$ felt few ill effects, but for the last three years I have suffered increasingly from numbness and tingling of the fingers on rising, which gradually got so bad that I was unable to fasten my collar without pain. . . . With great fortitude I stopped smoking for a whole month. At the end of a fortnight the dead hands were normal, I had no morning cough or sputum, and I rested like a baby. I then began to smoke again, 10 to 12 cigarettes daily. As a result the same syndrome, in modified form, is creeping on me again.

\section{A Plain Word}

Dr. I. GeIKIE-ĆOBB (London, N.W.1) writes: In commenting on my criticism of your use of the word " anatomized" you say that it is no new invention. I did not maintain that it was. I am well aware that it is not: indeed, it is to be found in the O.E.D. as a "v.t. \& i." I said, and with respect I repeat, that it is an ugly word and no writer with an ear for language should use it.

\section{Correction}

Through an error by the printer the word " anatomized" was unfortunately substituted for "atomized" in the final printing of the letter "Primary Atypical Pneumonia" from Professor C. H. Stuart-Harris last week (November 10, p. 1152, last line but one of para. 1).

\section{Obituary}

Dr. Edward Siddall Jackson, of Carnforth, Lancs, died suddenly on September 13. His death brought to an end over 100 years of medical practice in the same town by his father, grandfather, and great-grandfather. The younger son of the late Dr. E. S. Jackson, he was born in 1892, and educated at George Watson's College and Edinburgh University, at which he graduated M.B., Ch.B. in 1921. His medical studies were interrupted by service with the R.F.A. from 1914 to 1918. He then joined his father in practice, and remained in Carnforth until his death. He was essentially a family doctor. Having been born and brought up among his patients, he knew them, their parents, and their grandparents, and, later, their children and grandchildren. It was natural that he was esteemed as a friend as well as a doctor, and his cheerful disposition, kindly nature, and depth of sympathy endeared him to all who knew him. His busy practice left little time for relaxation, but he nevertheless contrived t $\delta$ play cricket and rugby football in his younger days, and in later life to acquire a wide and intimate knowledge of trees and wild birds. On many occasions he has taken me by country lanes to point out an unusual tree or the haunt of a rare bird. To accompany him on a country visit was an education and a delight. His elder son was killed in 1945 at Luzon in the Philippines while serving with the American Army. Dr. Jackson is survived by his wife and younger son, to whom the deepest sympathy will be extended.-J.W.

Dr. Harry Percival Foulerton, medical superintendent of Broadmoor Asylum from 1926 to 1937, died in his sleep on October 15 in his 78th year. He returned to London that day after a three weeks' holiday, and seemed to be well. He received his medical education at St. George's Hospital, and took the Conjoint Diploma in 1897 and the D.P.H. (R.C.P.S.) in 1900. After holding appointments as casualty officer at St. George's Hospital and house-physician at the Royal United Hospital, Bath, he began a long and useful career in the Civil Service in 1900 . He first served as a medical officer in Liverpool Prison and later at Holloway Prison until 1910. He was then appointed deputy medical superintendent at Broadmoor Criminal Lunatic Asylum. During the first world war he served as a captain in the R.A.M.C. with the late Sir John Baker, the medical superintendent, in charge of the insane German prisoners of war. who were detained in a special block of the institution. He became medical superintendent at Broadmoor in 1926 and retired in 1937. He then went to live at Yateley, in Hampshire, but during the last years of his life he lived in London. Foulerton made the care and treatment of the criminal lunatic his main life's work, and was peculiarly fitted for this difficult, exacting, and not infrequently dangerous task, meeting sudden emergencies with calm and unruffled precision. His prolonged experience made him a valuable colleague as one of the members appointed by the Home ${ }^{-}$Secretary to hold a medical inquiry under Section 2 (4) of the Criminal Lunatics Act, 1884, and he approached the day-to-day problems with the reflection that many of his patients might never be fitted to return to life in the outer world. So far as possible, therefore, he endeavoured to fit each patient into the most appropriate and comfortable place in the institution which could be safely given him. Foulerton was well suited to country life and obtained much satisfaction in his appointment. He had two sons by his first wife. The sympathy of his former colleagues and contemporaries will go out to them and his second wife, the daughter of the late Major-General and the Hon. Mrs. Mitford, and her son.-W. N. E.

Dr. Alan McKinstry Fleming died suddenly from a, coronary thrombosis at his home in Nairobi, Kenya, on October 17, at the age of 56 . He was educated at the University College School, London. Having enlisted in the 